\title{
Legitimacy of the Malays as the Sons of the Soil
}

\author{
Od. M. Anwar ${ }^{1}$, Wan Ahmad Fauzi Wan Husain@ Hashim $^{1}$, Junaidi Abu Bakar ${ }^{2}$ \& Zulayti Zakaria ${ }^{1}$ \\ ${ }^{1}$ Social and Humanity Sceinces Faculty, National University of Malaysia, Malaysia \\ ${ }^{2}$ Sultan Idris Educational University, Tajung Malim, Malaysia \\ Correspondence: Od. M. Anwar, Social and Humanity Sceinces Faculty, National University of Malaysia, 43600 \\ Bangi, Selangor, Malaysia. Tel: 60-3-8921-5290; 60-13-336-0077. E-mail: manwar@ukm.my; \\ maod7117@yahoo.com
}

Received: August 9, 2012 Accepted: September 30, 2012 Online Published: December 31, 2012

doi:10.5539/ass.v9n1p74 URL: http://dx.doi.org/10.5539/ass.v9n1p74

\begin{abstract}
This paper presents evidence to defend the Malay as legitimate sons of the soil. The arguments are supported by linguistic, archeological, paleoanthropological, prehistorian, botanical, genetic and forensic evidence. The bulk of the sources on indigenous concept of the sons of the soil are the Malay classical texts. Based those sources, it is argued that the Malays are entitled to be regarded as legitimate sons of the soil, firstly, their ancestors were not migrants, instead originated from the Nusantara region; secondly, their ancestors were the first who constituted the political establishment or effective administration in Nusantara in general and in Malaysia in particular; thirdly, the status of the Malay masses as the sons of the soil had been legitimized by the Malay Sultanates, a single supreme authority over all matter on the Malay sovereignty of all time till today; and, fourthly, the Malay themselves constituted the concept of sons of the soil and also the geo-political entity called Tanah Melayu (the Malay Land) long before the coming of foreign influences.
\end{abstract}

Keywords: colonial knowledge, migration theories, effective administration, international community's recognition, Malay classical texts

\section{Introduction}

Hitherto there have been challenges by the non-Malays against the Malays who regard themselves as the sons of the soil of this country (Malaysia). The most classic example of this was from the noted agitator Lim Ching Ean/Yan, a member of the Straits Settlements Legislative Council (1929-1933), who spoke to a Penang Chinese association in 1931 as follows:

Who said this is a Malay country? When Captain Light arrived, did he find Malays, or Malay villages? Our forefathers came here and worked hard as coolies-weren't ashamed to become coolies-and they didn't send their money back to China. They married and spent their money here, and in this way the Government was able to open up the country from jungle to civilization. We've become inseparable from this country. It's ours, our country (Cited from Roff 1967: 209).

In 1933, during his second term, he was hailed a folk hero among the Chinese as he walked out of the council chamber in protest against the government's refusal to fund Chinese and Tamil vernacular education because the British regarded the Chinese and Indians as non-natives (Tan Kim Hong 2007: 142; The Star, 7 February 2002). $\mathrm{He}$ is still celebrated. For instance, a subscriber to Malaysiakini who wrote about his 'contribution' under a title "Sacrifice a must on the road to unity" (http://www.malaysiakini.com/letters/95022, Retrieved 10 May 2012), and The Star (7 February 2002) regarded him as a Distinguished Son of Penang.

The last decades have seen the surge of more intensive challenges toward the Malay position as the sun of the soil especially among those so-called 'colonial knowledge' reviewers (e.g Kahn 2006, Vickers 2004, Nah 2003, Fernandez 1999). By using words such as 'contesting' and 'deconstruction' as their tools, in the guise of post-structural school of thought, they have attempted to deny or challenge the status of Malays as the sons of the soil. For instance, while in January 1948, Malcolm MacDonald, the Governor General of Singapore and Malaya, announced that "The Malays are the truest sons and daughters of the Malayan soil," (Broadcast Speech by the Governor-General, 4 January 1948. NAA A1838 413/2/1/4 Part 1, BTSEA - Malayan Constitutional Reforms), Sornarajah (2010: 107) says, "Bumiputera, literally, the 'children of the land.' The Malays are not indigenous to the land. There are the Orang Asli to Malaysia, whom the Malays themselves regard as the indigenous people." 
They seem to be more 'colonial minded' than the real pre-independence colonialists. For instance, speaking on the origin of the concept of Tanah Melayu (Malay Land), while Valentyn (1726, ed. 1885: 64-65), who was writing during the time before the coming of the British to this country, said "This country has generally been known since that time, during the early Melaka Sultanate, by the name "Tanah Malayu" and while Crawfurd (1856: 251) in nineteenth-century said "The Malays themselves call the peninsula Tanah Malayu, that is, the 'Malay land, or country of the Malays"" and while Winstedt (1966: 8) also said "By Malays it came to be termed 'Malay land' (tanah Melayu), though parts of Sumatra and Borneo are also 'Malay land' the continent of Europe still calls the country the Peninsula of Malacca," those 'colonialism minded speculators' insist that this concept was invented by the colonial British. Fernandez (1999: 47), for instance, writes:

It was the British too who gave geopolitical connotations to Malaya by calling it 'Malay land' i.e. Tanah Melayu, a term adopted by the Malay later. The term Tanah Melayu to mean land belonging to the Malays, was not a native construct. Early Malay texts had no such conception of statehood to encompass Malay. It would seem to me that prior to European colonialism these places were geographic rather than geo-political entities.

The same goes in dealing with the term sons of the soil. While Parmer (1957: 151) says, "the British favored the Malays on the theory that they are the sons of the soil to whom the British had treaty obligations" and while Winstedt (1966:16) also says, "The Malays have at least as much right to be regarded as the aboriginal people of Malaya as the English have to be called the aborigines of England," Nah (2003: 531) says:

I argue, is anxiety-producing for the 'Malay' new-Self, for its claims to being essentially 'indigenous' come under serious questioning when there is evidence that the Orang Asli have had deep(er) historical continuities in the land.

We deliberately use the word 'reviewers,' albeit scholars, because though seemingly critical in their views to contest and deconstruct the Malay identity, none of them configure their arguments based on primary sources. They seem quite sophisticated in 'name dropping'; quoting huge secondary sources from published literature (books and journals). For example, in their argumentation on the Malay origin, they are overwhelmed by migrations theories by heavily drawn, in fact expanded, the pre-war models. Fernandez (1999: 46), for instance, says:

The Malay history of origin was one of common history, on the migration of Malays to Malaya in two waves, the first being the proto-Malays (i.e. those we call the Orang Asli or aborigines) and the second, the deutero-Malays, the present Malay. The importance of a common history as the British wrote clearly became central towards later Malay understanding of the civilization in the region.

Most probably, skeptical readers would be satisfied with this explanation. However, as will be enlightened in this paper, this model is an outdated version of Malay origin theories. In fact, most scholars in Malay Studies have declared that those migration theories lack of scholarly input and unprofessionally done and are thus deemed to contradict scientific knowledge.

This paper, a rebuttal to those contestations and deconstructive speculations, offers concrete historical evidence which would demonstrate that the Malays are entitled to be regarded as the legitimate sons of the soil of Nusantara in general, and of Malaysia, in particular. Our argument is based on the following: 1) The Malay ancestors were originated from Nusantara, and for that we present evidence to reject those migration theories; 2) The Malays were the first people who constituted the political establishment with effective administration since the prehistoric period to the present-day Malay Sultanates; 3) The legitimacy of the Malay masses' claim to be regarded as the sons of the soil had been constituted by the legitimate, supreme indigenous institution, the Malay Sultanates, and 4) The Malays had constituted the geo-political entity, called Tanah Melayu (The Malay Land), on their own long before the coming of foreign influences.

With all the evidence which will be presented, we could charge those 'colonial knowledge' speculations as totally ignorant of the basic historical facts on Malay history.

\section{Methodology}

In dealing with the migration theories and the setting up of the first political establishments and effective administration in this region, this study refers to the original writings of the most noted scholars in the respective fields such as Robert Heine van Geldern (1945, 1950, 1952a, 1952b \& 1956), Diamond (2000 \& 2001), Bellwood (1991, 1997, 1998, 1995, 2005), Blust (1985 \&1999), Adelaar (2005), Nothofer (1997), Comrie (2001), Sykes et al. (1995), Solheim II (1970 \& 1982), Lamp (1964), Benjamin (1987 \& 2002), Hiroki Oota et.al 2001), 


\section{Detroit (2004) and Oppenhemeir (2006, 2004 \&1999).}

The main sources in the construction of indigenous concept of sons of the soil are the Malay classical texts such as the Malay Annals (Sejarah Melayu), Undang-Undang Melaka (1450-1750, MS 1780), Hikayat Merpati Mas dan Merpati Perak(1883. MS 1887), Adat Raja Melayu 1779, 1850 MSS 1817 (1873). In tracing the historical usage of the terms such as Tanah Melayu and sons of the soil in those classical texts, we also relied on the Malay Concordance Project (http://mcp.anu.edu.au/cgi-bin/tapis.pl. Retrieved 8 April 2012)-the most useful source of Malay studies in general, and we are most thankful to those people behind the project. This study also refers to the early nineteenth-century European accounts such as by Marsden (1811 \& 1812), Raffles (1830 \& 1817), Crawfurd (1819, $1852 \&$ 1856), Hamilton (1721/1970), Logan (1848), Wallace (1869) and Howison (1801).

\section{Malays Are Not Migrants}

Our first argument to defend the Malays as legitimate sons of the soil is based on the fact that their ancestors were not migrants, but originated from the Nusantara region. Our assertion is based on the following evidence: Firstly, ancient primates and fossils found in Nusantara are much older than those found in other regions either in Mainland Asia or in the Oceania. Secondly, Nusantara is one of the regions located in the Equatorial Belt, the most likely place for human settlement during the Pleistocene and Holocene periods because it was the only region which had the thinnest layer of ice during those periods. Other regions located in the Equatorial Belt during those periods were Arabian continent, central Africa and Amazon basin. This could be evidenced from high concentration of oil wells in the Equatorial Belt. Scientifically, oil wells were formed from living organisms, a sign of human existence in those regions. Whereas, geological studies show that regions located to the North of Tropic of Cancer and to the South of the Tropic of Capricorn were covered by ice for some kilometers.

Thirdly, it would be plainly unacceptable to assume there were no humans in the whole Nusantara region before the arrival of human beings from other regions. Fourth, there is not even single evidence that shows the centre (core) of Austronesian speakers had ever been in other part of the world other than Nusantara.

Fifth, archaeological artifacts such as ancient bronze (drums and axes), stone tools, and also linguistic data, fossil as well as botanical remains, should not be assumed as reliable scientific evidence to claim that the ancestors of Austronesian and Austroasia speakers groups were originated from southern China because they are too tiny and too fragmented to represent human civilization in the context of the vast region of Nusantara and of the period thousands of years ago. In fact, we wonder if they are truly representative of the prehistoric civilization, hence ancient people in the whole Southeast Asian region, or whether they only represent fringe areas.

Sixth, migration theories proposed by Hendrik Kern (1889-cited from Anceaux 1965), Robert Heine van Geldern (1945, 1950, 1952a, 1952b, \& 1956), Diamond (2000 \& 2001), Bellwood (1991, 1997, 1998, 1995, 2005), (Blust 1985 \&1999), Adelaar (2005), Nothofer (1997), Comrie (2001), and Sykes et al. (1995), as will be discussed at lengthy, could not be regarded as useful and valid way to find the homeland of Malay ancestors because they were based on fallacy derived from non-scientific facts and methodologies. Thus, they yield nothing other than fragmented, unfinished and half-baked conflicting theories.

\section{Rejection of the Migration Theories}

Those acquainted with the works of Solheim II (1970 \& 1982), Lamp (1964), Benjamin (1987 \& 2002), Hiroki Oota et.al 2001), Detroit (2004), Terrell (2004), Mohamed Anwar Omar Din (2011), and more importantly Oppenhemeir (1999, 2004 \& 2006), would probably be enlightened that those migration theories of Southeast Asian peoples have actually long been heavily criticized as invalid and obsolete for they do not seem to make any sense and almost absolutely opposed to scientific and empirical evidence. One of the most radical criticism is by Benjamin (1987: $109 \&$ 2002: 20) who says the constituent layer of a gigantic kueh lapis, layer cake theory, with the Negritos at the bottom, then the Senoi, followed by the so-called 'Proto-Malays' and the final and topmost layer supposedly made up of the 'Deutero-Malays,' much too often repeated in the history and geography textbooks of the last half-century, no longer seems acceptable to any professional prehistorian. Lamp (1964: 102) derives at the same conclusion that the spread of archaeological artifacts (such as Don Song and bronze axes) over such a wide Nusantara area indicates it was in some forms of commercial contacts with the southern fringes of the Chinese world, rather than to be perceived as evidences of human immigrations. Indeed, as a matter of fact, bronze Don Song drums for commercial purpose are still been produced till today by the people in the Red River Delta of northern Vietnam. Those who used Dong Song drums to suggest evidence of human immigrations had never referred to Heger Type Classification to justify the validity of their theories.

The migration theories also exhibit enduring methodological defects because inherently they are all laid, either 
deliberately or accidentally, on the basis of Sapir's paradigm (Sapir 1916) that assumed the place where observers think to have comparatively thicker, denser and diversified or higher variety of remains of archaeological, linguistic/cognates, fossil and botanical specimens, should be considered as the homeland of the people they studied. It had been on this basis that those migration theories pointed to Yunnan or to Tonkin or to Taiwan or to Southern Ocean Sea as the homeland of the Austronesian ancestors. For example, Comrie (2001:28) writes:

The internal diversity among the Formosan languages is greater than that in all the rest of Austronesian put together, so there is a major genetic split within Austronesian between Formosan and the rest. Indeed, the genetic diversity within Formosan is so great that it may well consist of several primary branches of the overall Austronesian family.

This paradigm, however, would never bring conclusive and definite scientific and objective answers as their results totally depend on how the observers determined and gauged the thickness, denseness, diversified and variety of those remains. Since there are always observers who would claim, as often than not, the place where they started doing the research as having comparatively thicker, denser, diversified and higher variety of archaeological, linguistic (cognates), fossil and botanical remains than other places, the results could also lead to a reverse direction in the migration movement, for example, Southeast Asia or Nusantara region as the homeland of Austronesian, had the observers started their studies in this region. It has been out of these differences in determining and gauging the thickness, denseness, diversified and variety of those remains that had brought a never ending race between 'Express Train from Taiwan' (represented by Bellwood 1998) on one side, and 'Slow Boat from Polenisia." (represented by Oppenhemeir 2006) on the other side.

On the other hand, Sapir's paradigm potentially yield results that are opposed to the obvious historical facts. For instance, should Sapir's paradigm - with its keywords 'thicker,' 'denser' and 'higher variety' of remains-had been used as a standard research procedure to explain the origin of indigenous people in African continent with the same way as it had been used to explain the origin of Southeast Asian people, it could imply also that those indigenous people in the African were originated from ghettos in Manhattan (United States of America). This is because even a single ghetto in that American metropolis has much thicker, denser and higher variety of whatever specimen as compared to any place in Africa.

There is another serious defect in the migration theories: they have been operating on the premise that the Malays (in the guise of Austronesian speakers) were from a single ancestor's stock, whereas in reality the Malays have always been polygenic-vis., not from a single ancestor. In fact, there is no clear cut between the so-called Austroasian speakers from the so-called Austronesian speakers, both in the cultural-linguistic as well as in their genetic elements (Benjamin 1987: 109 \& 2002: 2-4; Maruyama et.al. 2010: 165). The most recent genetic study by a Japanese independent body (which did not involve a single Malay) undertaken among the Malays in Kuala Lumpur in 2010 reaffirmed those assumption that exert the Malays are homogenous or from single stock is misleading (Maruyama et.al. 2010: 165). The result of that study would probably be true of much of other Malays in Sumatera, the whole of Peninsula, Kalimantan, the Philippines, in fact Nusantara as a whole.

The polygenic features of the Malays does not only hold for the present but also prevalent for the whole of the Malay historical times. For instance, the founder of Melayu-Srivijaya kingdom, Dapunta Hyang Çri Yacanaca, could hardly be regarded as having fully Austronesian or Austroasian blood, but rather of mixed native Nusantaran, Javanese and Indian blood. This hypothesis is based on his very name: 'Hyang' is Nusantaran name, 'Dapunta' is Javanese and 'Çri Yacanaca' is Indian. It goes the same with the founder of fifteenth-century Melaka Sultanate, Parameswara, and also the most prestigious Malay scholar, Tun Seri Lanang. Those are only a few examples of mixed gene of Malays as there are so many that could not be easily quantified. Even all the Prime Ministers of Malaysia are of that kind.

In fact, historical facts in general would conclude that genetic studies are equally a matter for speculation as other disciplines. Though their methodologies were seemingly sophisticated with scientific laboratory apparatus and specimens, as well as technical jargons, the genetic studies stumbled into two most fundamental shortcomings: 1) to get indisputable testimony and general consensus on the acceptance of genetic prototype (DNA or gene sample) of who are the native, and in the case of Nusantaran, who are the real native Malays; and 2) there is no direct connection between genetics and the homeland (Terrell 2004: 586-587). In practice, the scientists in genetic studies rely or attest their findings heavily on the results of linguistic, archeological, paleoanthropological, prehistory, botanical and forensic studies (Terrell 2004: 586-587). Terrell's latter example is very much true in the case of genetic studies in Nusantara. It has been a usual practice, when they found that the genetic of the people in Nusantara have the same genetic features with the people in southern Taiwan or 
southern China, those scientists in genetic studies will refer to what had been stated by linguists, archeologists, paleoanthropologists, prehistorian and botanists experts. That is to say, one should not take for granted that genetic test could tell us the homeland or the place of origin of the people in Southeast Asia. Genetic studies cannot stand on their own but rather have to be supported by linguistic, archeologistic, paleoanthropologistic, prehistorical and botanical findings which all operated on Sapir's paradigm (Sapir 1916) as well.

\section{The First to Establish Effective Administration}

The second argument to defend the Malay should be regarded as legitimate sons of the soil is based on the fact that their ancestors were the first people who constituted the political establishment or effective administration in Nusantara in general and in Malaysia in particular. This could be proved by the $3^{\text {rd }}$ century B.C. Indian ancient texts Ramayana and Vayu Purana which had recorded an entity called 'Malayadvipa' in Nusantara. There are other evidence that supported this argumentation. The second century A.D. Ptolemy's Greek text Geography also recorded the entity called Malayu-kulon. Later, the 672/692 A.D. I-Tsing's (Yijing) account had also recorded the existence of the Malay political establishment called 'Melayu-Srivijaya' (I-Tsing 1896, transl. by Takakusu). This kingdom was later succeeded by the fifteenth-century Melaka Sultanate. According to Portuguese sources, Afonso De Albuquerque (transl. Birch 1774) and Tome Pires (1512/1944), the founder of Malay Melaka kingdom, Parameswara, married a daughter of the ruler of Pasai (Acheh) in 1414 and converted to Islam. During the reign of Sultan Mansor Shah, Sultan Alauddin Shah and Sultan Mahmud Shah I, with Tun Perak as their Bendahara (Prime Minister), the Melaka Sultanate's influence appeared to have extended over the neighboring kingdoms of Bengkalis, Bintang, the Carimon Islands, Muar, and the Sumateran states of Kampar, Siak, Aru, Rokan and Indragiri, and on the northern peninsula of Kelantan, Manjong, Bruas, Terengganu, Perak, Pahang and Kedah. To date there is no evidence that shows there had ever been a Chinese or Indian political establishment in this region before or after that periods, except, of course, the Republic of Singapore in the 1960s.

It has been a universal truth or generally accepted that those who first established political control are entitled to claim sovereignty over the land. As they were the first to establish, those Malay political establishments are prevailing factor to be regarded as the legitimate sovereign institution in this region. Hitherto this position has been well recognised and respected by the international communities including the British during their administration in the Peninsular-even though sometimes they used the terms 'British Possession' (Cameron 1865) and 'British Malaya' (Swettenham 1906). For example, in the nineteenth-century Cameron (1865: 125-126) stated:

The Malays are entitled to be looked upon as the first rulers and the reprehensive people of Singapore and the Malay peninsula; for the aborigines were never numerous, nor do they appear at any time to have raised up a system of government, but only to have wandered about in scattered tribes; and though their traditions point to a time when they checked the Malayan invasion, it seems to me that this was in all likelihood only the driving back of a few stranger prahus, and not the repelling of an invasion. It will be seen from the short sketch which I have given of the early history of Singapore, that there at all events the Malays were met by no resistance, and as they had greatly increased in numbers before they were driven from the island (Palembang) by the Javanese to seek a new settlement on the mainland of the peninsula near Malacca, it is highly improbable that their landing there could have been seriously opposed by a few rudely armed tribes possessing no organization.

In essence, Cameron was referring to the coming of Parameswara and his ruling house from Palembang, Sumatera, to Melaka which had resulted in the establishment of the Melaka Sultanate in early fifteenth-century. Cameron (1865: 126-127) detailed the formation of the Malay political establishment as follows:

The Malays that we find in Singapore and the British possessions in the Straits (vis. The Malay States of Peninsula) are but in part the representatives of the entire race. The independent native states of the peninsula are entirely peopled by them, and from these and from Sumatra, constant conditions are being made to the Malay population of the British possessions.

Unlike the nomadic tribes of the Aborigines, the Malays or the peninsula have always been lovers of good order and an established government. In their independent states they have first a Sultan, who is all powerful; under him are datuhs, or governors, selected from among the men of rank, and under these again there are pangulus, or magistrates, all standing very much in their relation to the people as our own nobility stood in feudal times to the people of England. There are, therefore, easily governed, and sensible of the benignity of English law, they form the most 
peaceable and probably the most loyal portion of our native population.

Cameron's account is not an isolated hypothesis because almost all the eighteenth and nineteenth century Europeans observers, such as De Eredia (1613), Valentyn (1884), Marsden (1811 \& 1812), Raffles (1830 \& 1817), Crawfurd (1819, 1852 \& 1856), Hamilton (1721/1970), Logan (1848), Wallace (1869) and Howison (1801) gave the same accounts. Scrutiny on those accounts would immediately indicate the international communities' recognition that the Malays as natives, as indigenous, and the legitimate son of the soil at par with the Aborigines.

\section{The Masses Had Been Legitimized by the Malay Sultanates}

The third argument to defend the Malay position as legitimate sons of the soil is based on the status of the Malay masses as the sons of the soil had been legitimized by the Malay Sultanates. By virtue of having been the first to constitute the political establishment with prolonged effective administration, the Malay Sultanates had been recognised by the international communities as the sovereign and single legitimate indigenous political institution.

This legitimizing of the mass is embedded within the definition of the sons of the soil itself which could be traced from a mysterious usage of the word 'tanah' or sometime 'bumi' (both could be translated as 'soil' or 'clay') which consistently appears in the Malay classical texts such as the Malay Annals (Sejarah Melayu), Undang-Undang Melaka (1450-1750, MS 1780), Hikayat Merpati Mas dan Merpati Perak (1883. MS 1887), and Adat Raja Melayu 1779, 1850 MSS 1817 (1873). In the Malay Annals (Sejarah Melayu ed. Shellabear 1977: 138; A.Samad Ahmad's 1986: 187) the usage of the word 'tanah' (soil) is as follows:

Segala Melayu itu $\underline{\operatorname{tanahmu}}$, seperti kata Arab Al-'abdi tinu'lmaulahu, yang hamba itu tanah tuannya.

Brown's translation of MS Raffles No. 18 as follows:

the Malays are your $\underline{\text { clay }}$ as the Tradition says, 'Al-'abdu tinu'l-murabbi', which being interpreted is 'the slave is as it were (? the clay of) his master (Malay Annals transl. by C.C. Brown 2009 from first published in 1952: 124)

The usage of the word 'tanah' in Undang-Undang Melaka could be found in the phrase "hamba itu tanah tuannya"; in Hikayat Merpati Mas dan Merpati Perak in "hamba dengan bumi tanah hamba"; and in Adat Raja Melayu in "Mangkubumi itu, artinya ialah yang memerintah, memberi kebajikan atas bumi yang dilenggarai raja itu."

These phrases, therefore, could qualify the Malays as the sons of the soil. For reasons of limited space, we would only analyze the Malay Annals. The keyword is 'the soil.' In essence it is about the relationship between the subjects and the Ruler. Literally, the phrase "Segala Melayu itu tanahmu" in the Malay Annals could be translated as 'that all Malays are thy soil,' whereas the phrase "yang hamba itu, tanah tuannya" as 'that the subjects are the soil of their owner.' In the first phrase, the word 'soil' clearly means 'the subjects' and the word 'mu' which means 'thy' in English is a possessive pronoun which refers to the Ruler. When it says 'tanahmu' ('thy' soil) it refers to the 'people' (or the subjects) who were owned by the Ruler.' Thus, the whole phrase "Segala Melayu itu tanahmu" here could be translated as 'all the Malays are thy soil'-with thy referring to the Sultan.

In the second phrase the word 'soil' also means 'the subjects.' However, this phrase has a possessive noun 'tuannya' which means 'the owner of the soil.' Thus, the phrase "yang hamba itu, tanah tuannya' could be translated as 'the subjects are the soil owned by its owner.' The owner here refers to the Malay Sultan.

Both phrases, 'the soil' and 'its owner,' could be defined as to refer to 'the subjects of the Ruler.' It is in this connotation that had brought out the legitimate criteria of ordinary people as sons of the soil. In a nutshell, sons of the soil among the masses refers to persons who are the subjects of the Malay ruler on one hand, and being accepted by the Malay rulers as their subjects, on the other hand. It is in this vein the ordinary people or the mass had been constituted as the sons of the soil. In essence, sons of the soil in the Malay context is characterized by the loyalty and readiness to menyembah (to bow to) the Sultan. Menyembah (to bow) or hamba raja here are in the sense to become obedient subjects of the Malay Sultanate, not as the slaves of the Sultan.

\section{Sons of the Soil and Tanah Melayu Phrases}

The fourth argument to defend the Malay position as legitimate sons of the soil is based on the facts that the Malay themselves constituted the concept of sons of the soil and also the geo-political entity called Tanah Melayu (the Malay Land) long before the coming of foreign influences. It is a grave mistake to speculate that 
these concepts are recent and of modern Europeans inventions as there are abundant indigenous sources that reveal these terms had existed and been well known among the Malay natives long before the coming of the Western powers. The proof for this assertion lies in the accounts left by De Eredia (1613), Valentyn (1884), Marsden (1811 \& 1812), Raffles (1830 \& 1817), Crawfurd (1819, 1852 \& 1856), Hamilton (1721/1970), Logan (1848), Wallace (1869) and Howison (1801). For instance, Valentyn (1726, ed. 1885: 64-65) writes:

The Malays crossed under this Prince (SIRI TOORI BOWNA) from the island of Sumatea to the opposite, now the Malay Coast, and more especially to its North-East point, known as 'Oejong Tanah,' that is, "the extremity of the country," and known among geographers as 'Zir Baad' which means in Persian 'below wind' (to leeward), hence receiving a long time afterwards also the new name 'the people below wind' (to leeward), or else 'Easterlings' (above all the other nations in the East), from this name having been given afterwards also to some of their neighbours or other Easterlings. This country has generally been known since that time by the name 'Tanah Malayu,' i.e. 'the Malay territory' or else 'the Malay Coast,' comprising in a larger sense all the country from that very point or from the $2^{\text {nd }}$ degree till the $11^{\text {th }}$ degree North latitude and till Tenasserim, though, taking it in a more limited sense, only that country is understood, which now belongs under the governorship and jurisdiction of Malacca and its environs; they are, therefore, also called 'Orang Malayu,' i.e. the Malays, whilst all the other Malays, either closely or far, as those of Patani, Pahang, Peirah (Perak), Keidah (Kedah), Djohor, Bintan, Lingga, Gampar, Harus, and others in this same country or on the islands of Bintang, Lingga, or Sumatra, are also called Malays, but always with the addition of the name of country where they come from, as for instance: Malayu-Djohor. Malayu-Patani, \&c,\&c.

John Crawfurd (1856: 251), a contemporary of other early nineteenth-century European observers such as Marsden, Leyden and Raffles, writes:

The Malays themselves call the peninsula Tanah Malayu, that is, the 'Malay land, or country of the Malays;' and they designate its wild inhabitants, speaking the Malay language, as the Orang banua, literally 'people of the soil;' or as we should express it, 'aborigines.' The term 'land of the Malays' is, however, given to the Peninsula by civilised Malays, perhaps only on account or its being the only country almost exclusively peopled by Malays; whereas in Sumatra and Borneo they are intermixed with other populations. The term 'son of the soil,' applied by these civilised Malays may in the same manner, be used by them only to distinguish the rude natives from themselves claiming to be foreign settlers. The expressions, however, would seem to imply that the civilised Malays considered the wild tribes, speaking the same language with themselves, as the primitive occupants of the land. But the same wild tribes, speaking the Malay language, although not distinguished as 'son of the soil,' exist also in Sumatra, and more especially on its eastern side opposite to the Peninsula: and they are found also, in several of the islands lying between those countries, extending even to Bancoa and Billiton.

Both writers precisely informed us that the concepts of sons of the soil and Tanah Melayu were invented by the indigenous Malays themselves, not by foreigners. These accounts sufficiently reflect the truth as both writers were writing when Western knowledge had not yet penetrated into the mind of the indigenous people in this part of the world.

It is another mistake to assume that early Malay texts had no such concept of statehood to encompass Malaya (as claimed by Fernandez 1999: 47). As shown in Table 1, even with uncritical eyes one would admit there are abundant of Malay classical texts which had used the term Tanah Melayu (The Malay Land) long before the coming of Western influences.

Table 1. The term Tanah Melayu (the Malay land) in indigenous classical texts (pre-industrial eras)

\begin{tabular}{lll}
\hline Date/Period & Titles & Frequency \\
\hline 1603 & Tajal-Salatin (ed. Roorda \& ed. Khalid) & 1 \\
$1625-1899$ & Warisan Warkah Melayu & 1 \\
$\sim 1700$ (MS 1849) & Hikayat Hang Tuah & 46 \\
$1796-1849$ & Surat Beriluminasi Raja Nusantara & 1 \\
1811 (MS 1811) & Hikayat Perintah Negeri Benggala & 3
\end{tabular}


1838

1842 , rev. 1849

1854

1855 (MS 1893)

$<1859$

1861 (MS 1878)

1865

1866 (MS 1890)

1883 (MS 1883, 1932)

1889 (MS 1889+)
Pelayaran Abdullah ke Kelantan

1

Hikayat Abdullah bin 'Abdul Kadir

2

Pelayaran Abdullah ke Mekah

1

Hikayat Siak

2

Syair Kumbang Mengindera $\quad 1$

Carita Bangka 3

Salasilah Melayu dan Bugis $\quad 2$

Tuhfat al-Nafis 1

Hikayat Pahang $\quad 1$

Hadiqat al-Azhar wa'l-Riyahin 1

Source: Malay Concordance Project (http://mcp.anu.edu.au/cgi-bin/tapis.pl) [Retrieved 8 April 2012]

Those texts confirm what had been recorded by Valentyn (1726) and Crawfurd (1856) as mentioned above. In fact, as mentioned in their above quotations, these eighteenth-century and nineteenth-century European observers implicitly stated it had been the Europeans who had taken the words from locals and translated it into English, not the other way round. Of course, not all the terms Tanah Melayu mentioned in those Malay classical texts refer to Malay Peninsula; some refers to Melaka. However, most of them refer to the current Malay Peninsula. For example, the phrase "tanah Melayu" in Hikayat Hang Tuah, which appear 46 times, means the Malay land and it refers to the Malay Peninsula (see also Reid 2002). A seventeenth-century Portuguese observer, De Eredia (1613: 8), also gave the same account, "Throughout all this continental territory of Ujontana the Malaya language is used, and the natives describe themselves as 'Malayos." Thus, even though some observers may refer 'Ujontana' as southern part of the Peninsula but in essence De Eredia did not mean there was no unified Malay political establishment called Tanah Melayu:

..starting point by the Island of Pulo Catay in the region of Pattane (Pattani), situated in the east coast in 8 degrees of latitude, the pass round to the other or western coast of Ujontana, to Taranda and Ujon Calan situated in the same latitude in district of Queda (Kedah): this stretch of territory lies within the region of "Malayos" and the same language prevail throughout (De Eredia 1613: 8).

Actually, he was using the old name for the Malay Peninsula as the term 'Ujontana' had been used before the Melaka Sultanate expanded its influence to constitute the Malay identity.

\section{Conclusion}

We think we have presented enough evidence to establish the legitimacy of the Malays as the sons of the soil. If all accounts presented here-such as there are no other places in the Asian region which had the oldest ancient primates and fossils been found other in Nusantara, the Nusantara was located in the Equatorial Belt which is the most suitable place for humans to settle during the Pleistocene and Holocene periods, it is illogical to imagine the whole Nusantara was totally inhibited before the arrival of human beings from outside. There is not even a single evidence to show the centre of Austronesian speakers had ever been in other parts of the world, there are fundamental defects in all migration theories, and the Malays were the first to constitute prolong political establishments as well as to have constituted geo-political entity (the Malay Land)-are taken into consideration. We have had ample evidence to conclude that the Malays are no less native, no less indigenous, and no less sons of the soil as the Aborigines or any other natives in this region such as Negrito (Kintaq, Lanok, Kensiu, Jahai, Mendriq and Bateq), Senoi (Temiar, Semai, Mahu Meri, Che Wong, Ja Hut and Semoq Beri) and Malayu (Orang Selatar, Jakun, Orang Kuala, Orang Kanaq, Temuan and Semelai) in the Peninsular; Iban, Bidayuh, Bisaya, Kayan, Kedayan, Kelabit, Kenyah, Melanau, Murut, Penan and Punan in Sarawak; and Kadazandusun (Kadazan + Dusun), Murut, Bajau, Bisaya, Kadayun, Orang Sungai, Orang Laut and Brunei in Sabah.

If all those accounts presented in this paper are perceived as not really the earliest then what else could be considered as the earliest in Southeast Asian context as far as written and other sources are available? If one goes on to argue on linguistic, archeological, paleoanthropological, prehistorian, botanical, genetic and forensic basis, we then revert to nothing because, as stated earlier, migration theories yield nothing other than half-baked conflicting theories.

\section{References}

Ahmad, A. S. (Ed.). (1986). Sejarah Melayu. Kuala Lumpur: Dewan Bahasa dan Pustaka. 
Anceaux, J. (1965). Linguistic Theories about the Austronesian Homeland. Bijdragen tot de Taal-, Land- en Volkenkunde, 121(4), 417-432. http://www.kitlv-journals.nl/index.php/btlv/article/viewfile/2633/3394

Barnard, T. (Ed.). (2004). Contesting Malayness: Malay Identity across Boundaries. Singapore: Singapore University Press, National University of Singapore.

Bellwood, P. (1991, July). The Austronesian Dispersal and the Origin of Languages. Scientific American, 265, 88-93. Retrieved from http://www.nature.com/scientificamerican/journal/v265/n1/full/scientificamerican0791-88.html http://dx.doi.org/10.1038/scientificamerican0791-88

Bellwood, P. (1997). Prehistory of the Indo-Malaysian Archipelago. Honolulu: University of Hawaii. Retrieved from http://www.scribd.com/doc/36787303/BELLWOOD-PETER-Prehistory-of-the-Indo-Malaysian-Archipelag o

Bellwood, P. (1998). Taiwan and the Prehistory of the Austronesians-speaking Peoples. Review of Archaeology, 18, 39-48.

Bellwood, P., \& Sanchez-Mazas, A. (2005, June). Human Migrations in Continental East Asia and Taiwan: Genetic, Linguistic, and Archaeological Evidence. Current Anthropology, 46(3), 480-485. Retrieved from http://www.jstor.org/discover/10.1086/430018?uid=3738672\&uid=2\&uid=4\&sid=21101074878523 http://dx.doi.org/10.1086/430018

Bellwood, P., James, F., \& Tryon, D. (1995). The Austronesians: Historical and comparative perspectives. Department of Anthropology, Australian National University.

Benjamin, G. (1987). Ethnohistorical perspectives on Kelantan's prehistory. In Nik Hassan Shuhaimi Nik Abd. Rahman (Ed,). Kelantan Zaman Awal (pp. 127-235). Kota Bharu: Perbadanan Muzium Negeri Kelantan.

Benjamin, G. (2002). On Being Tribal in the Malay World. In Geoffrey Benjamin, \& Cynthia Chou (Eds,). Tribal Communities in the Malay World. Historical, Cultural and Social Perspectives (pp. 7-76). Singapore: Institute of Southeast Asian Studies.

Birch, W. D. G. (1774). The Commentaries of the Great Afonso Dalboquerque, Second Viceroy of India. London: The Hakluyt Society.

Blust, R. A. (1985). The Austronesian Homeland: A Linguistic Perspective. Asian Perspectives, 26, 46-67.

Blust, R. A. (1999). Subgrouping, circularity and extinction: some issues in Austronesian comparative linguistics. In E. Zeitoun, \& P. J. K. Li (Eds.), Selected papers from the Eighth International Conference on Austronesian Linguistics (pp. 31-94). Taipei: Academia Sinica.

Broadcast Speech by the Governor-General. (1948, January 4). NAA A1838 413/2/1/4 Part 1, BTSEA - Malayan Constitutional Reforms.

Cameron, J. (1865). Our tropical possessions in Malayan India: being a descriptive account of Singapore, Penang, Province Wellesley, and Malacca - their peoples, products, commerce, and government. London: Smith, Elder.

Comrie, B. (2001). Languages of the world. In Mark Aronoff, \& Janie Rees-Miller (Eds,). The Handbook of Linguistics (pp. 19-42). Oxford: Blackwell.

Crawfurd, J. (1852). A grammar and dictionary of the Malay language. London: Smith Elder.

Crawfurd, J. (1856). A Descriptive Dictionary of the Indian Islands \& Adjacent Countries. London: Bradbury \& Evan.

Crawfurd, J. A. (1819). History of The Indian Archipelago: Containing an Account of the Manners, Arts, Languages, Religions, Institutions, and Commerce of its Inhabitants (Vol. 2). Edinburgh: Printed for Archibald Constable and Co. Edinburgh; and Hurst, Robinson, and Co. Cheapside, London.

De Eredia, E. G. (1930). Description of Malaca and Meridional India and Cathay in Three Treatises: Addressed to His Catholic Royal Majesty Dom Phelippe, King of Spain, Our Sovereign, Transl. by J. V. Mills. Journal of the Malayan Branch of the Royal Asiatic Society, 8(1), 1-288.

Detroit, F. (2004). Homo Sapiens in Southeast Asian Archipelago: Holocene Fossil Evidence with Special Reference to Funerary Practices in East Java. In Truman Simanjunrak, Ingrid H. E. Pojoh, \& Mohammad 
Hisyam (Eds.), Austronesian and the Ethnogeneses of People in Indonesian Archipelago: Proceeding of the International Symposium (pp. 186-204). Jakarta: LIPI Press.

Diamond, J. (2001, March 8). Polynesian origins: 'Slow boat to Melanesia?' Nature, 410, 166-167.

Diamond, J. M. (2000). Taiwan's gift to the world. Nature, 403, 709-710. http://dx.doi.org/10.1038/35001685

Fernandez, C. (1999, July). Colonial Knowledge, Invention and Reinvention of Malay Identity in Pre-Independence Malaya: A Retrospect. Akademika, 55, 37-57.

Hamilton, A. (1970, 1717, 1930). A New Account of the East Indies (Part 2). Amsterdam: N. Israel \& New York: Da Capo Press,

Hong, T. K. (2007). Chinese in Penang: A Pictorial History. Penang: Areca Books.

Howison, J. (1801). Dictionary of the Peninsula of Malacca, the island of Sumatra, Jawa, Borneo, Pulo Pinang, \& c. \& c. T.P. London: Langman, Hurst, Rees, Orme and Brown.

I-Tsing. (1896). A Record the Buddhist Religion as Practised in India and the Malay Archipelago (A.D. 671-695). Translated by J. Takakusu. Oxford: The Clarendon Press.

Kahn, J. S. (2006). Other Malays: Nationalism and Cosmopolitanism in the Modern Malay World. Singapore: Singapore University Press.

Khor, N. (2008). Sacrifice a must on the road to unity. Retrieved May 10, 2012, from

Lamp, A. H. (1964). Early History. In Wang Gungwu (Ed.), Malaysia: A Survey (pp. 98-119). Singapore: Donald Moore Books Ltd.

Logan, J. R. (1848). The Journal of the Indian Archipelago and Eastern Asia. Penang: the Mission Press.

Longman, Hurst, Rees, and Brown. (1821). Malay Annals. Translated by John Leyden. London: Longman, Hurst, Rees, and Brown.

Marsden, W. (1811). The History of Sumatra Containing an Account of the Government, Laws, Customs and Manners of the Native Inhabitants (3rd ed.). London: J. M'creery, Black-Horse-Court.

Marsden, W. (1812). A grammar of the Malayan language. London: Longman.

Maruyama, S., Nohira-Koike, C., Minaguchi, K., \& Nambiar, P. (2010). MtDNA Control Region Sequence Polymorphisms and phylogenetic analysis of Malay Population Living in or Around Kuala Lumpur in $\begin{array}{lllll}\text { Malaysia. International Journal Legal Medicine, } & 124, & 165-170 .\end{array}$ http://dx.doi.org/10.1007/s00414-009-0355-6

Mohamed Anwar Omar Din. (2011). Asal-Usul Orang Melayu: Menulis Semula Sejarahnya (The Malay Origin: Rewrite Its History). Jurnal Melayu, (7), 1-82. Retrieved from $\mathrm{http} / / /$ www.ukm.my/e-melayu/index.php?option=com_content\&view=article\&id=32\&Itemid=33\&lang=en

Moor, J. H. (1968). Notices of the Indian Archipelago and Adjacent Countries. London: Franks Cass \& Co. Ltd.

Nah, A. M. (2003). Negotiating indigenous identity in postcolonial Malaysia: beyond being 'not quite/not Malay'. Social Identities: Journal for the Study of Race, Nation and Culture, 9(4), 511-534.

Nothofer, B. (1997). Dialek Melayu Bangka. Bangi: Penerbit Universiti Kebangsaan Malaysia.

Oota, H., Kurosaki, K., Pookajorn, S., Ishida, T., \& Ueda, S. (2001). Genetic study of the Paleolithic and Neolithic Southeast Asians. Human Biology, 7(2), 225-232. http://dx.doi.org/10.1353/hub.2001.0023

Oppenheimer, S. (1999). Eden in the East: The Drowned Continent of Southeast Asia (New ed.). London: Phoenix.

Oppenheimer, S. (2004). Out of Eden: The Peopling of the World. London: Constable and Robinson.

Oppenheimer, S. (2006). Response to Peter Bellwood and Jared Diamond (2005): On explicit 'replacement' models in Island Southeast Asia: a reply to Stephen Oppenheimer.' World Archaeology, 38(4), 715-717. http://dx.doi.org/10.1080/00438240600963494

Parmer, J. N. (1957, October). Constitutional Change in Malaya's Plural Society. Far Eastern Survey, 26(10), 145-152. http://dx.doi.org/10.2307/3023957

Pires, T. (1944). The Suma Oriental (Vol. 2). London: Hakluyt Society.

Raffles, L. (1830). Memoir of the life and public services of Sir Thomas Stamford Raffles. London: Murray. 
Raffles. T. S. (1994). The History of Java. Kuala Lumpur: Oxford University Press.

Reid, A. (2001, October). Understanding Melayu (Malay) as a Source of Diverse Modern Identities. Journal of Southeast Asian Studies, 32(3), 295-313. http://dx.doi.org/10.1017/S0022463401000157

Roff, W. R. (1967). The Origins of Malay Nationalism. Kuala Lumpur: Oxford University Press.

Sapir, E. (1916). Time Perspective in Aboriginal American Culture. Ottawa: Geological Survey Department of Mines, Canada. Memoir 90, Anthropological Series No. 13.

Shellabear, W. G. (Ed.). (1977). Sejarah Melayu. Kuala Lumpur: Fafar Bakti.

Solheim II, W. G. (1970). Northern Thailand, Southeast Asia, and World Prehistory. Asian Perspectives, XIII, $145-162$.

Solheim II, W. G. (1982). A Look at "L`Art Prebouddhique de la Chine et de l'Asie du Sud-est et son influence en Oceanie" Fourty Years After. Asian Perspectives, XXII(2), 165-205.

Sornarajah, M. (2010). The International Law on Foreign Investment. Cambridge: Cambridge University Press. http://dx.doi.org/10.1017/CBO9780511841439

Swettenham, F. (1906). British Malaya an Account of the Origin and Progress of British Influence in Malaya. London: John Lane the Bodley Head.

Sykes, B., Leiboff, A. D., Low-Beer, J., Tetzner, S., \& Richards. M. (1995). The origins of the Polynesians: an interpretation from mitochondrial lineage analysis. American Journal Human Genetic, 57, 1463-1475.

Terrell, J. E. (2004, December). Introduction: 'Austronesia' and the great Austronesian migration. World Archaeology, 36(4), 586-591. http://dx.doi.org/10.1080/0043824042000303764

The Malaysian Branch of the Royal Asiatic Society. (1952-2009). Malay Annals. Translated by C. C. Brown. Kuala Lumpur: The Malaysian Branch of the Royal Asiatic Society.

Valentyn, F. (1884, June). Valentyn's Description of Malacca. Journal of the Straits Branch of the Royal Asiatic Society, 13, 49-246.

Van Geldern, R. H. (1945). Prehistoric research in the Netherlands Indies. In Science and Scientists in the Netherlands Indies. New York, Board for the Netherlands Indies, Surinam and Curacao.

Van Geldern, R. H. (1950a). Heyerdahl's Hypothesis of Polynesian Origins: A Criticism. Geographical Journal, 116, 183-192. http://dx.doi.org/10.2307/1789382

Van Geldern, R. H. (1952b). Voyaging Distance and Voyaging Time in Pacific Migration. Geographical Journal, 118, 108-110. http://dx.doi.org/10.2307/1791267

Van Geldern, R. H. (1952c). Some problems of migration in the Pacific. Wiener Beitrage zuriat Kulturgeschichte und Linguistik, 9, 313-362.

Van Geldern, Robert Heine. (1956). Conceptions of state and kingship in Southeast Asia. SEAP Publications.

Vickers, A. (2004). 'Malay Identity': Modernity, Invented Tradition and Forms of Knowledge. In Timothy P. Barnard (Ed.), Contesting Malayness: Malay Identity Across Boundaries (pp. 25-55). Singapore: NUS Press.

Wallace, A. R. (1922). The Malay Archipelago - the land of the Orang-Utan and the birds of paradise - a narrative of the travel with the studies of man and nature. London: MacMillan and Co., Limited St. Martin's Street.

Winstedt, R. O. (1966). Malaya and its History. London: Hutchinson University Library Press. 